Check for updates

Cite this as: $B M J 2020 ; 371: m 4472$ http://dx.doi.org/10.1136/bmj.m4472 Published: 17 November 2020

\section{Testing times for the government's favoured antibody kit}

In this article by Armstrong (BMJ 2020;371:m440, doi:, published 16 November 2020), there was an error regarding the purchase of one million $\mathrm{AbC}-19$ tests by the government-this was announced in October, not September. This has been corrected online. 